\title{
PENGGUNAAN ENZIMA PROTEOLITIK PADA INDUSTRI PENYAMAKAN KULIT
}

\author{
Oleh: Prayitno
}

\section{ABSTRACT}

Enzime is naturaly protein which has katalistic properties in the chemical reaction. The use of enzymes in leather processing has been well known for many years. One of the enzime which have big role in the leather processing is protease. It is used in the unhairing and bating processes. The use of protease on the leather processing can reduce the environment pollution especially in unhairing process.

\section{ABSTRAK}

Inzima adalah merupakan protein yang terjadi secara alami mempunyai sifat katalis pada suatu reaksi kimia. Penggunaan enzima pada proses penyamakan kulit telah lama dikenal pada industri penyamakan kulit, salah satujenis enzima yang sangat berperan dalam proses penyamakan kulit adalah enzima protease yang digunakan pada proses bating. Penggunaan enzima proteolitik dalam penyamakan kulit dapat menekan terjadinya pencemaran lingkungan, terutama penggunaannya pada proses buang bulu.

\section{PENDAHULUAN}

Proses pengolahan kulit mulai dari penyediaan bahan baku hingga kulit jadi memerlukan tahapan-tahapan proses dalam menggunakan bermacam-macam bahan kimia dan padat air. Pada setiap tahapan proses akan dihasilkan limbah yang potensial untuk menyebabkan terjadinya pencemaran lingkungan.

Selain menggunakan bahan-bahan kimia, pada proses penyamakan kulit juga digunakan beberapa jenis enzima mengingat kulit merupakan bahan yang berasal dari bahan alami dan mengandung protein dan lemak yang cukup tinggi.

Penggunaan enzima pada proses pengolahan kulit telah dikenal beberapa puluh tahun yang lalu. Awalnya digunakan kotoran sapi untuk menghilangkan bulu pada kulit sapi dan kulit domba atau kambing, bahkan pada dua ribu tahun yang lalu telah digunakan kotoran dari burung merpati, mekanisme prosesnya pada waktu itu tidak diketahui dengan pasti, bahwa proses tersebut merupakan mekanisme kerja dari enzima proteolitik yang dihasilkan oleh bakteri tertentu yang ada pada kotoran tersebut. Penggunaan cara diatas sulit dilakukan kontrol juga untuk mengetahui kapan proses tersebut dilakukan sehingga kulit tidak akan mengalami pembusukan. Dengan berkembangnya ilmu pengetahuan, enzima proteolitik kini dapat diproduksi secara komersial untuk proses penyamakan kulit dan penggunaannya dapat dilakukan secara terkontrol. Pada proses tertentu penggunaan enzima proteolitik dapat menekan pencemaran yang ditimbulkan. 


\section{Sifat enzim proteolitik}

Enzima proteolitik merupakan enzima yang dapat mengurai atau memecah ikatan peptida protein, enzima ini dikenal dengan nama protease. Protease banyak dihasilkan oleh pankreas hewan bertulang belakang, tanaman serta mikrobia. Sebagaimana enzima pada umumnya, daya katalitik dari protease banyak dipengaruhi oleh beberapa faktor :

a. Derajat keasaman $(\mathrm{pH})$

Aktivitas katalitik enzima mempunyai kisaran $\mathrm{pH}$ tertentu, pada $\mathrm{pH}$ tersebut enzima akan mempunyai aktivitas katalitik yang optimal. Kisaran $\mathrm{pH}$ enzima protein berbeda-beda tergantung pada jenis serta penghasil protease. Pepsin mempunyai $\mathrm{pH}$ optimum 1,8 arginase optimum katalitiknya pada $\mathrm{pH} 10$ enzima protease yang dihasilkan pada Bacillus tertentu mempunyai $\mathrm{pH}$ optimum antara $7,5-9,0$

b. Pengaruh suhu

Seperti pada reaksi-reaksi kimia, kenaikan suhu akan meningkatkan reaksi kimia, kenaikan suhu akan meningkatkan aktivitas enzima sampai pada suhu optimum yang apabila suhu dinaikkan akan menghambat aktivitas bahkan bisa merusak enzima.

Suhu optimum untuk aktivitas enzima proteolitik bervariasi bergantung pada jenis penghasil enzima tersebut, pada umumnya suhu optimum enzima proteolitik sesuai dengan suhu pertumbuhan mikrobia penghasil.

c. Zat penghambat

Aktivitas enzima dipengaruhi oleh adanya zat penghambat akan berkaitan dengan enzima, aibatnya enzima menjadi in aktif dan tidak dapat menghidrolisa enzima. enimara zat penghambat kerja enzima adalah logam-logam berat.

\section{PROSES ENZYMATIS PADA PENYAMAKAN KULIT}

a. Proses Unhairing

Proses unhairing merupakan proses untuk melepaskan bulu dari kulit hewan yang akan disamak. Proses ini pada metode yang biasa digunakan dilakukan pada tahapan proses liming (pengapuran). Untuk penyempurnaan proses buang bulupada proses liming perlu ditambahkan Natrium Sulphida. Limbah bulu yang dihasilkan dengan proses ini akan hancur, hal ini akan menyulitkan dalam penanganannya dan juga timbulnya gas $\mathrm{H} 2 \mathrm{~S}$ yang berbahaya.

Penelitian penggunaan enzima protease untuk proses unhairing telah banyak dilakukan, Raju (1996) telah melakukan penelitian untuk menghilangkan bulu dengan menggunakan extracellulair protease yang diisolasi dari Bacillus Sp.
Media yang digunakan untuk pertumbuhan mikrobia Bacillus Sp. Terdiri dari :

$\begin{array}{ll}\text { ckstrak yeast } & 0,15 \% \\ \text { ckstrak beef } & 0,15 \% \\ \text { peptone } & 0,5 \% \\ \text { glucose } & 0,1 \% \\ \text { natrium khlorida } & 0,53 \% \\ \text { natrium phosphat (dibasic) } & 0,36 \% \\ \text { natrium phosphat (monobasic) } & 0,13 \% \\ \text { calcium khlorida } & 100 \mathrm{mM}\end{array}$

$\mathrm{pH}$ disesuaikan menggunakan $\mathrm{NaOH}$ hingga $\mathrm{pH} 7$.

Hasil enzima maksimum sesudah inkubasi selama 18 jam sampai dengan 24 jam pada suhu $37^{\prime} \mathrm{C}$ dengan pengadukan konstan dengan kecepatan $300 \mathrm{rpm}$. Aktivitas enzima diukur dengan larutan casein, sebagai berikut : untuk setiap $2.5 \mathrm{ml}$ larutan $1 \%$ casein dalam larutan buffer borat $\mathrm{pH} 9,0$ sebanyak $50 \mathrm{mM}$ diinkubasikan pada suhu $40^{\prime} \mathrm{C}$ selama 10 menit, kemudian ditambahkan larutan enzima I ml, inkubasikan campuran pada suhu $40^{\prime} \mathrm{C}$ selama 20 menit. Aktivitas enzima kemudian dihentikan dengan penambahan 1,5 $\mathrm{ml}$ larutan $30 \%$ asam tri khloro asetat (TCA). Kemudian didiamkan pada temperatur kamar selama 20 menit, saring dengan kertas Whatman No. 4, kemudian fraksi larutan diukur absorbancenya pada panjang gelombang $280 \mathrm{~nm}$. Aktivitas dari 1 unit enzima adalah setara dengan $1 \mathrm{mg}$ tyrosine yang dilepaskan pada percobaan tersebut. Hasil dari percobaan Raju menunjukan bahwa maksimum aktivitas enzima dicapai pada $\mathrm{pH} 7,5$ dan $\mathrm{pH} 9$ serta pada temperatur $37^{\prime} \mathrm{C}$. Pada proses Unhairing dapat dicapai selama 18-24 jam pada temperatur 32-37'C. Juga enzima menunjukan kestabilan pada suhu $20-50^{\prime} \mathrm{C}$. Enzima yang diperlukan sampai $2 \%$ dari berat pelt dan $3 \%$ berat pelt dapat sebagai penghilang bulu pada bagian leher

Hasil penelitian dari Raju menunjukan data-data sebagai berikut :

\begin{tabular}{|l|c|c|}
\hline Konsentrasi enzyme & Tensile strength $(\mathrm{kg} / \mathrm{cm} 2)$ & Elongation $(\%)$ \\
\hline Control & $139,11 \pm 6,68$ & $73,20 \pm 7,12$ \\
$1 \%$ enzima & $201,65 \pm 4,85$ & $71,22 \pm 5,44$ \\
Control & $138,35 \pm 1,23$ & $69,91 \pm 10,33$ \\
$2 \%$ enzym & $209,50 \pm 1,10$ & $62,54 \pm 6,75$ \\
Control & $165,70 \pm 1,61$ & $70,16 \pm 10,65$ \\
$3 \%$ enzima & $215,60 \pm 4,09$ & $65,86 \pm 0,715$ \\
\hline
\end{tabular}


British Leather Configuration (BLC) juga mengenalkan suatu proses unhairing tanpa menggunakan kapur, dengan menggunakan enzima proteolitik tertentu. Penggunaan enzima proteolitik pada proses buang bulu mempunyai keuntungan dalam waktu prosesnya, jika pada proses biasa menggunakan bahan kimia diperlukan waktu 2 hari dengan enzima hanya memerlukan waktu 1 hari. Dari hasil uji kelemasan dan kuat sobek kulit hasil percobaan dengan enzima dibandingkan dengan cara kimiawi menunjukkan data sebagai berikut :

\begin{tabular}{|l|c|c|c|c|}
\hline Proses & $\begin{array}{c}\text { Bending } \\
\text { length }(\mathrm{cm})\end{array}$ & $\begin{array}{c}\text { Flexxural } \\
\text { rigidity }(\mathrm{g} \mathrm{cm})\end{array}$ & $\begin{array}{c}\text { Modulus } \\
(\mathrm{g} / \mathrm{cm} 2)\end{array}$ & $\begin{array}{c}\text { Tear strength } \\
(\mathrm{kg} / \mathrm{mm})\end{array}$ \\
\hline Lime free proses & $4,2 \pm 0,5$ & $5,6 \pm 2,0$ & $39 \pm 14$ & $8,2 \pm 2,5$ \\
Proses kontrol & $4,2 \pm 0,6$ & $6,2 \pm 1,6$ & $34 \pm 10$ & $10,5 \pm 2,0$ \\
\hline
\end{tabular}

Dari data diatas terlihat pada kulit yang diproses dengan enzima lebih lemas dibanding kulit yang diproses biasa, akan tetapi kekuatan sobeknya sedikit lebih rendah dari proses yang biasa.

b. Proses Bating

Tujuan utama dari proses bating adalah untuk menghilangkan non kolagen protein untuk menjadikan kulit lunak dan mempunyai kekuatan yang lebih baik, kegagalan menghilangkan protein non kolagen menyebabkan serabur-serabut akan mengeras pada saat pengeringan sehingga kulit akan kehilangan fleksibilitas. Melihat tujuannya tersebut, pada proses bating komponen utama yang harus ada dalam agensianya adalah enzima proteolitik. Enzym proteolitik dapat berasal dari pancreas atau dari mikroorganisme.

Efisiensi/aktifitas proses tergantung pada temperatur, $\mathrm{pH}$ dan waktu proses. Protease dari pancreas aktif antara $\mathrm{pH} 7,5-8,5$, protease dari fungi aktif antara $\mathrm{pH}$ $3,5-5$, sedangkan protease dari bakteri akan aktif pada $\mathrm{pH}$ alkali, mulai dari $\mathrm{pH} 6$ bahkan ada yang mencapai pH 10. Deselnicu M dan Bratulesco V. (1994) dalam penelitiannya menggunakan enzima yang bersifat asam pada proses bating menunjukkan adanya kenaikan luas kulit yang diperoleh dari wetblue ke kulit finish dibandingkan dengan penggunaan alkali enzima sebagai berikut:

\begin{tabular}{|l|c|c|c|}
\hline & Luas kulit wetblue(sqf) & Luas kulit samak(sqft) & kenaikan(\%) \\
\hline Kontrol & 263,0 & 279,6 & 6,3 \\
Test & 257,0 & 284,1 & 10,2 \\
\hline
\end{tabular}

Widowati T.P (1997) dalam penelitiannya menggunakan Protease dari Bacillus
Sp UGM5 untuk Agensia Bating menyimpulkan bahwa penggunaan agensia bating dari enzima Protease Bacillus Sp. UGM5 tidak memberikan beda nyata terhadap sifat fisik maupun kimiawi kulit kras dibandingkan bating dengan agensia bating komersial.

Dengan bating akan menaikan sifat kemuluran dan elastisitas dari kulit kras.

\section{KESIMPULAN}

Dari data-data hasil penelitian oleh beberapa ahli seperti tersebut diatas bahwa penggunaan enzima protease pada proses penyamakan kulit sangat diperlukan selain akan meningkatkan kualitas dari produk akhir kulit, juga dilihat dari segi pencemarannya akan dapat memperbaiki kualitas limbah yang dikeluarkan terutama pada proses buang bulu, karena bulu utuh yang diperoleh akan mudah dalam penanganannya.

\section{DAFTAR PUSTAKA}

1. British Journal Configuration, (1992), Studies of ime Free Unhairing/Opening Up, BLC Journal, August 1992.

2. Desellnicu M. and Bratulesco V. (1994); A New Enzyme Process for Improved Yield and Softer leather Technical Note, JAICA, Vol. 89, 1994.

3 Raju A. A., Chandrababu, N. K., Cs (1996), Ecofriendly Enzymatic Dehairing Using Extracelullair Protease Bacillus Sp Isolate, JAICA, Vol 91, May 1996

4. Widowati, T. P. (1997); Karakterisasi Protease Bacillus Sp. UGM5 dan Penggunaannya Sebagai Agensia Bating, Program Studi Ilmu Peternakan UGM.

5. Wilson J.N. (1988), Enzymes in Tannery Catalysts for Progress, JAICA, Vol. 83, 1988. 